\title{
Developmental surveillance in primary health care: absence of child development milestones and associated factors
}

\section{Katherine Solís-Cordero 1}

iD https://orcid.org/0000-0002-6012-0245

Claudia Nery Teixeira Palombo 2

https://orcid.org/0000-0002-0651-9319

Luciane Simões Duarte 3

https://orcid.org/0000-0001-9173-607X

Rebeca Ishi Munhoz 4

https://orcid.org/0000-0003-0163-1122

\author{
Aurea Tamami Minagawa Toriyama 5 \\ iD https://orcid.org/0000-0003-0288-5714 \\ Ana Luiza Vilela Borges 6 \\ https://orcid.org/0000-0002-2807-1762 \\ Elizabeth Fujimori 7 \\ https://orcid.org/0000-0002-7991-0503
}

1,2,3,5,6,7 Escola de Enfermagem. Universidade de São Paulo. Av. Dr. Eneas de Carvalho Aguiar, 419. Cerqueira Cesar. São Paulo, SP, Brasil. CEP: 05.403-000. E-mail: katherine.solis22@usp.b

${ }^{4}$ Hospital Alemão Oswaldo Cruz. São Paulo, SP, Brasil.

\begin{abstract}
Objectives: to identify the absence of one or more general child development milestones and by domains, and associated factors.

Methods: cross-sectional study with 334 children under three years of age conducted out at Primary Health Care Facilities, São Paulo, Brazil. The dependent variable was the general child development and the fine motor, gross motor, social and psychic domains evaluated using the Developmental Surveillance Instrument of the Brazilian Ministry of Health. Data were obtained by interviewing the mothers and observing children. The chi-square test and logistic regression analyses were used.

Results: absence of one or more milestones of general child development was found in $52.1 \%$ of children, especially, in the fine motor domain. We found an association between general child development with age $(O R=4.4 ; C 195 \%=2.0-9.9)$ and the place of stay of the child who does not attend daycare (OR = 3.7; CI95\%= 1.3-10.5).

Conclusions: the absence of one or more milestones of general child development is high and associated with aspects of the child and the environment. This emphasizes the importance of promoting developmental surveillance in Primary Health Care Facilities among health professionals using the official instrument recommended by the Brazilian Ministry of Health.

Key words Child development, Child health, Primary health care, Health promotion, Nursing
\end{abstract}




\section{Introduction}

Evidence shows that in low- and middle-income countries, children under the age of five are at risk of not reaching their maximum development potential.1,2 According to the Inter-American Development Bank, despite the progress in health and nutrition conditions of the child population in the Latin American region, data related to child development are incipient. ${ }^{3}$ In Brazil, there is a high prevalence of suspected developmental delay ranging from $21 \%$ to $53 \%, 4-7$ mainly in populations with less social insertion. ${ }^{8}$

Child development is a complex process that begins from conception and involves aspects of physical growth, neurological, behavioral, cognitive, social and emotional maturation. It is the result of the interaction of biological, socio-environmental, health and nutritional characteristics, such as: birthweight, 4,9 nutritional status, 4,10 hemoglobin level, 9 breastfeeding, 10 income and educational level of parents, $4,11,12$ maternal age and care.12,13 Additionally, there has been an increase in the use of electronic devices, even among young children, which can also have adverse effects on the development. 14

In Brazil, since 1984, the surveillance of children's growth and development has represented one of the main axes of care to children's health. However, only when a significant reduction in infant morbidity and mortality rates was achieved that greater emphasis was given to the promotion and surveillance of child development, with the enactment of public policies such as the National Policy for Comprehensive Child Health Care (Portuguese acronym: PNAISC) 15 and the Legal Framework for Early Childhood. 16 Despite these policies and the existence of an official instrument included in the Child Health Handbook, studies show its underutilization by health professionals. ${ }^{17}$ In addition, the scientific production using this instrument for the identification of children with probable developmental problems is scarce.

In this context, the objectives of this study were to identify the absence of one or more general child development milestones and by domains, and the associated factors in primary care.

\section{Methods}

This is a cross-sectional, descriptive-analytical study in which was used data from a larger study that evaluated the growth, development and nutrition of children under three years of age. 18
It was developed in Primary Care Facilities in a city in the state of São Paulo, Brazil, with about 50 thousand inhabitants. For the sample size calculation, inappropriate eating practices $(p=0.50)$ were considered as parameter, a requirement of the broader study, as well as the total population of children under three years of age registered in the 12 primary care facilities of the city $(\mathrm{N}=3904), 95 \%$ confidence level and margin of error of $p=0.05$. The calculation for a finite population indicated the need for a sample of 350 children. The percentage distribution of children registered in each primary care facility was calculated to obtain a representative and proportional sample to the number of minors registered in each health center. Inclusion criteria were children under three years of age registered in primary care facilities, accompanied by their biological mothers, while exclusion criteria were children with health problems (genetic, neurological and metabolic) and twins.

The selection of children comprising the sample was non-probabilistic, therefore, all mothers of children under three years of age who presented to the health service during the data collection period were invited to participate.

Data were collected from February to April 2013, through interviews with mothers at health centers using a form prepared by the researchers and pre-tested. The interviews were performed by 11 nurses and a nursing student, who received theoretical-practical training to make the evaluations, including child development evaluation. Quality control was ensured through the accompaniment and rigorous supervision of researchers throughout the data collection process and $10 \%$ of mothers were contacted by telephone to corroborate the information obtained.

In this study, were used children's aspects of age in months $(<12 ; 12 \mid-24 ; \geq 24)$ and sex (male/female). The nutritional aspects analyzed were birth weight in grams $(<2,500 ; \geq 2,500)$, nutritional status (eutrophy, excess weight, thinness), presence of anemia in those older than 6 months (not anemic/anemic), breastfeeding of children under 24 months at the time of the interview (yes/no) and introduction of timely complementary feeding (timely/untimely). The socio-environmental aspects included were maternal age in years $(<20 ; 20 \mid-35$; $\geq 35)$, maternal education in years of study $(\leq 8 ;>8)$, maternal work outside the home (no work/work), well-child care at the health center (yes/no), child attendance at daycare (does not attend/attends), place of stay of the child who does not attend daycare (parents' house/another place), main care- 
giver of the child who does not attend daycare (mother/others), and the daily time of television exposure in hours of children aged one year or older $(<1 ; \geq 1)$.

The dependent variable of the study was general child development and the fine motor, gross motor, social and psychic domains, evaluated using the Developmental Surveillance Instrument of the Ministry of Health of Brazil, 19 the official instrument used in primary care during the study period. This instrument is as a guide for the observation and identification of children with probable developmental problems by evaluating the presence or absence of development milestones domains (except for the psychic domain) included in most of the more used scales, such as the Denver, Sheridan and Gesell. 20 For this study, the results obtained were classified as the presence of all milestones or the absence of one or more development milestone for the respective age group evaluated.

The nutritional status was evaluated through the anthropometric measurements of weight and height following the recommended techniques. ${ }^{21}$ For children under two years of age, a digital pediatric scale (Welmy brand) and a wooden anthropometer were used; and for those children older than two years, the platform-type anthropometric scale (Welmy brand) with an attached anthropometer was used. For the classification of nutritional status, the z-score of the Body Mass Index (BMI) for age was used with the following cut-off points: thinness $(\mathrm{BMI}<-2)$; eutrophy (BMI $\geq-2$ and $\leq 1)$; and excess weight [including risk of being overweight (BMI $>1)$, overweight $(\mathrm{BMI}>2$ and $\leq 3)$ and obesity $(\mathrm{BMI}>3)] .21$

To assess the presence of anemia, a capillary blood sample was obtained by finger stick for the measurement of hemoglobin, performed with a portable $\mathrm{AGABE}^{\circledR}$ brand hemoglobinometer. Anemia was defined as hemoglobin levels below $11 \mathrm{~g} / \mathrm{dL}$ in children older than 6 months of age. 22

Breastfeeding in children under 24 months was evaluated at the time of the interview. It was defined as feeding with breast milk, regardless of any milk supplement consumption or not. Lastly, the introduction of supplementary feeding was considered timely when it began after the sixth month, and not timely when any other food or liquid was introduced before six or after eight months of life together with breast milk or artificial milk. ${ }^{23}$

The database was built by double typing in the Epi-Info version 3.5.1 software. The Anthro program was used for analysis of nutritional status and the Stata version 15 was used for statistical analysis. The results were described by absolute and relative frequencies, means and standard deviation. The chisquare test was applied to examine the differences between the two proportions of child development (general and by domain) according to child and socio-environmental variables.

The aspects associated with the general child development dependent variable were assessed by logistic regression. The independent variables were: age and sex of the child; well-child care at the health center; attendance at daycare; place of stay of the child who does not attend daycare; and main caregiver of the child who does not attend daycare. The variable daily time (hours) of television exposure was not included in the regression model, since only children older than one year were evaluated. The maternal education variable was used to adjust the multiple regression model. Only the variables that presented association $p<0.20$ in the bivariate analysis were included in the multiple regression. The entry of each variable in the model followed the order of statistical significance, that is, those with the lowest $p$-value were assigned first. A significance level of $p=0.05$ was adopted.

This study was approved by the Research Ethics Committee of the School of Nursing at the University of São Paulo (CAAE: 02081612.7.0000.5392). All participating mothers signed the informed consent form.

\section{Results}

A total of 399 mothers were invited to participate in the study. Of these, 35 did not agree to participate and six children did not meet the eligibility criteria (two with neurological diseases, one was not a biological child and three were twins). Out of the 358 children, there was a loss of 24 due to incomplete information on child development, thereby resulting in a sample of 334 children included in the study.

More than half of the sample was less than one year old $(60.5 \%)$, with a predominance of the male sex $(54.8 \%)$, more than a quarter were overweight $(27.2 \%)$, there was high proportion of anemia $(41.5 \%)$ and of untimely introduction of complementary feeding $(81.2 \%)$. It was also found that more than half of children presented absence of one or more general child development milestones (52.1\%), with a higher proportion of absence of milestones in the fine motor domain, followed by the psychomotor, social and psychic (Table 1).

Table 2 shows that most mothers were between 20 and 35 years old $(72.3 \%)$, had more than eight years of study $(66.4 \%)$ and at the time of the inter- 
view, they did not have a job outside the home (61.6\%). Only $12.3 \%$ of children attended daycare and three-quarters of children older than one year (74.8\%) were exposed to television for an hour a day or more.

Tables 3 and 4 present the proportions of the developmental domains according to child and socio-environmental variables. In the four domains, the absence of one or more milestones showed significantly different proportions for the child's age $(p<0.001)$ and for the daily time of television exposure in the psychomotor $(p=0.008)$ and social

Table 1

Distribution of children according to child, nutritional and child development aspects. São Paulo, SP, Brazil, 2013 $(\mathrm{N}=334)$.

\begin{tabular}{|c|c|c|}
\hline Aspects & $\mathbf{N}$ & $\%$ \\
\hline \multicolumn{3}{|l|}{ Child } \\
\hline \multicolumn{3}{|l|}{ Age (months) } \\
\hline Mean (SD) & \multicolumn{2}{|c|}{$12.0(9.8)$} \\
\hline$<12$ & 202 & 60.5 \\
\hline $12 \vdash 24$ & 78 & 23.3 \\
\hline$\geq 24$ & 54 & 16.2 \\
\hline \multicolumn{3}{|l|}{ Sex } \\
\hline Male & 183 & 54.8 \\
\hline Female & 151 & 45.2 \\
\hline \multicolumn{3}{|l|}{ Nutritional } \\
\hline \multicolumn{3}{|l|}{ Birthweight (grams)* } \\
\hline$<2500$ & 33 & 10.2 \\
\hline$\geq 2500$ & 292 & 89.8 \\
\hline \multicolumn{3}{|l|}{ Nutritional status* } \\
\hline Eutrophy & 222 & 67.9 \\
\hline Excess of weight & 89 & 27.2 \\
\hline Low weight & 16 & 4.9 \\
\hline \multicolumn{3}{|c|}{ Anemia ( $\geq 6$ months of age)* } \\
\hline Not anemic & 121 & 58.5 \\
\hline Anemic & 86 & 41.5 \\
\hline \multicolumn{3}{|c|}{ Breastfeeding at the time of the interview ( $<24$ months of age $)^{*}$} \\
\hline Yes & 168 & 61.3 \\
\hline No & 106 & 38.7 \\
\hline \multicolumn{3}{|c|}{ Introduction of complementary feeding* } \\
\hline Timely & 51 & 18.8 \\
\hline Not timely & 220 & 81.2 \\
\hline \multicolumn{3}{|c|}{ Child development } \\
\hline \multicolumn{3}{|c|}{ Global child development } \\
\hline Present & 160 & 47.9 \\
\hline Absent & 174 & 52.1 \\
\hline \multicolumn{3}{|c|}{ Fine motor domain of child development } \\
\hline Present & 236 & 70.7 \\
\hline Absent & 98 & 29.3 \\
\hline \multicolumn{3}{|c|}{ Gross motor domain of child development } \\
\hline Present & 249 & 74.5 \\
\hline Absent & 85 & 25.5 \\
\hline \multicolumn{3}{|c|}{ Social domain of child development } \\
\hline Present & 256 & 76.9 \\
\hline Absent & 77 & 23.1 \\
\hline \multicolumn{3}{|c|}{ Psychic domain of child development } \\
\hline Present & 271 & 81.4 \\
\hline Absent & 62 & 16.6 \\
\hline
\end{tabular}

*Information was not obtained for the entire sample. 
( $p=0.012)$ domains. The absence of milestones in the psychic domain was significantly different for the variables control of the well-child care at the health center $(p=0.002)$, place of stay of the child who does not attend daycare $(p=0.006)$ and the main caregiver of the child who does not attend daycare $(p=0.027)$.

The results of the bivariate and multiple analysis are shown in Table 5. In the raw analysis, the absence of one or more general child development milestones was associated $(p<0.20)$ with the variables age, sex, place of stay of the child who does not attend daycare and primary caregiver of the child who does not attend daycare.

In the final multiple analysis model adjusted for maternal education, the age and place of stay of the child who does not attend daycare maintained a significant association with general child development. Children aged 24 months or older were 4.4 times more likely to have absence of one or more general child development milestones, compared to children younger than 12 months. Children who did not attend daycare and stayed in another place were 3.7 times more likely to have absence of one or more general child development milestones, compared to children who stayed at their parents' home.

\section{Discussion}

The absence of one or more general child development milestones was high among children under three years of age in much higher proportions than those found in similar studies, which were $35.5 \% 5$

\section{Table 2}

\begin{tabular}{|c|c|c|}
\hline Aspects & $\mathbf{N}$ & $\%$ \\
\hline \multicolumn{3}{|c|}{ Socio-environmenta/* } \\
\hline \multicolumn{3}{|c|}{ Maternal age (years) } \\
\hline Mean (SD) & \multicolumn{2}{|c|}{$27.2(6.7)$} \\
\hline$<20$ & 39 & 12.1 \\
\hline $20 \vdash 35$ & 232 & 72.3 \\
\hline$\geq 35$ & 50 & 15.6 \\
\hline \multicolumn{3}{|c|}{ Maternal education (years of study) } \\
\hline Mean (SD) & \multicolumn{2}{|c|}{$10.0(3.2)$} \\
\hline$\leq 8$ & 111 & 33.6 \\
\hline$>8$ & 219 & 66.4 \\
\hline \multicolumn{3}{|c|}{ Maternal work outside the home } \\
\hline No work & 204 & 61.6 \\
\hline Work & 127 & 38.4 \\
\hline \multicolumn{3}{|c|}{ Well-child care at the health center } \\
\hline Yes & 292 & 91.8 \\
\hline No & 26 & 8.2 \\
\hline \multicolumn{3}{|c|}{ Child attendance at daycare } \\
\hline No attendance & 292 & 87.7 \\
\hline Attendance & 41 & 12.3 \\
\hline \multicolumn{3}{|c|}{ Place of stay of the child who does not attend daycare } \\
\hline Parents' house & 263 & 90.7 \\
\hline Another place & 27 & 9.3 \\
\hline \multicolumn{3}{|c|}{ Primary caregiver of the child who does not attend daycare } \\
\hline Mother & 261 & 88.2 \\
\hline Others & 35 & 11.8 \\
\hline \multicolumn{3}{|c|}{ Daily time (hours) of television exposure ( $>1$ year of age) } \\
\hline Mean (SD) & & \\
\hline$<1$ & 31 & 25.2 \\
\hline$\geq 1$ & 92 & 74.8 \\
\hline
\end{tabular}

*Information was not obtained for the entire sample. 


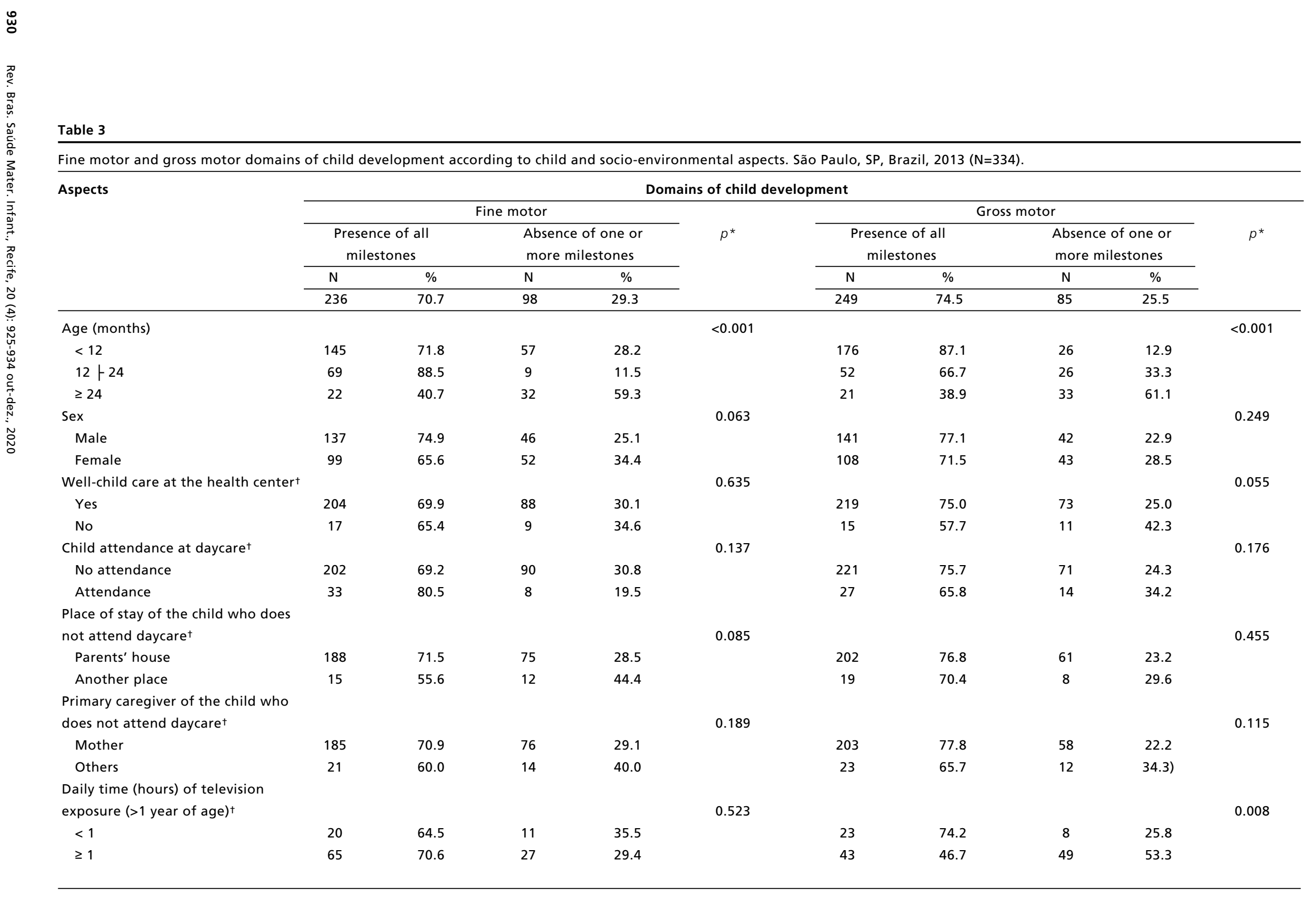

*Chi-square test; ${ }^{+}$Information was not obtained for the entire sample. 
Social and psychic domains of child development according to child and socio-environmental aspects. São Paulo, SP, Brazil, 2013 (N=334).

Aspects

Child development domain

\begin{tabular}{|c|c|c|c|c|c|c|c|c|c|}
\hline \multicolumn{4}{|c|}{ Social } & \multirow{4}{*}{$p^{*}$} & \multicolumn{4}{|c|}{ Psychic } & \multirow{4}{*}{$p^{*}$} \\
\hline \multicolumn{2}{|c|}{$\begin{array}{c}\text { Presence of all } \\
\text { milestones }\end{array}$} & \multicolumn{2}{|c|}{$\begin{array}{l}\text { Absence of one or } \\
\text { more milestones }\end{array}$} & & \multicolumn{2}{|c|}{$\begin{array}{c}\text { Presence of all } \\
\text { milestones }\end{array}$} & \multicolumn{2}{|c|}{$\begin{array}{l}\text { Absence of one or } \\
\text { more milestones }\end{array}$} & \\
\hline $\mathrm{N}$ & $\%$ & $\mathrm{~N}$ & $\%$ & & $\mathrm{~N}$ & $\%$ & $\mathrm{~N}$ & $\%$ & \\
\hline \multirow[t]{2}{*}{256} & 76.9 & 77 & 23.1 & & 271 & 81.4 & 62 & 18.6 & \\
\hline & & & & $<0.001$ & & & & & $<0.001$ \\
\hline 179 & 88.6 & 23 & 11.4 & & 185 & 92.0 & 16 & 8.0 & \\
\hline 42 & 53.8 & 36 & 46.2 & & 55 & 70.5 & 23 & 29.5 & \\
\hline \multirow[t]{2}{*}{35} & 66.0 & 18 & 34.0 & & 31 & 57.4 & 23 & 42.6 & \\
\hline & & & & 0.982 & & & & & 0.558 \\
\hline 140 & 76.9 & 42 & 23.1 & & 151 & 82.5 & 32 & 17.5 & \\
\hline \multirow{2}{*}{116} & 76.8 & 35 & 23.2 & & 120 & 80.0 & 30 & 20.0 & \\
\hline & & & & 0.200 & & & & & 0.002 \\
\hline 223 & 76.6 & 68 & 23.4 & & 241 & 82.8 & 50 & 17.2 & \\
\hline \multirow[t]{2}{*}{17} & 65.4 & 9 & 34.6 & & 15 & 57.7 & 11 & 42.3 & \\
\hline & & & & 0.841 & & & & & 0.316 \\
\hline 223 & 76.6 & 68 & 23.4) & & 239 & 82.1 & 52 & 17.9 & \\
\hline \multirow[t]{2}{*}{32} & 78.1 & 9 & 21.9) & & 31 & 75.6 & 10 & 24.4 & \\
\hline & & & & 0.313 & & & & & 0.006 \\
\hline 205 & 78.0 & 58 & 22.0 & & 221 & 84.4 & 41 & 15.6 & \\
\hline \multirow[t]{2}{*}{18} & 69.2 & 8 & 30.8 & & 17 & 63.0 & 10 & 37.0 & \\
\hline & & & & 0.189 & & & & & 0.027 \\
\hline 203 & 77.8 & 55 & 22.2 & & 218 & 83.9 & 42 & 16.1 & \\
\hline \multirow[t]{2}{*}{23} & 67.6 & 11 & 32.4 & & 24 & 68.6 & 11 & 31.4 & \\
\hline & & & & 0.012 & & & & & 0.637 \\
\hline 24 & 77.4 & 7 & 22.6 & & 21 & 67.7 & 10 & 32.3 & \\
\hline 47 & 51.6 & 44 & 48.4 & & 58 & 63.0 & 34 & 37.0 & \\
\hline
\end{tabular}

* Chi-square test; $\dagger$ Information was not obtained for the entire sample. 
Bivariate analysis and final multiple logistic regression model between the absence of one or more general child development (GCD) milestones and child and socio-environmental aspects. São Paulo, SP, Brazil, 2013 ( $N=334$ ).

\begin{tabular}{|c|c|c|c|c|c|c|c|}
\hline \multirow[t]{2}{*}{ Aspects } & \multicolumn{2}{|c|}{ Absence GCD } & \multicolumn{2}{|c|}{ Bivariate } & \multicolumn{2}{|c|}{ Final model* } & \multirow[t]{2}{*}{$p^{\dagger}$} \\
\hline & $\mathrm{N}$ & $\%$ & $\mathrm{OR}_{\text {crude }}$ & $\mathrm{Cl} 95 \%$ & OR $_{\text {Adjusted }}{ }^{*}$ & $\mathrm{Cl} 95 \%$ & \\
\hline Age (months) & & & & & & & $<0.001$ \\
\hline$<12$ & 89 & 44.1 & 1.0 & - & 1.0 & - & \\
\hline $12 \vdash 24$ & 43 & 55.1 & 1.6 & $0.9-2.6$ & 1.7 & $0.9-3.1$ & \\
\hline$\geq 24$ & 42 & 77.8 & 4.4 & $2.2-8.9$ & 4.4 & $2.0-9.9$ & \\
\hline Sex & & & & & & & 0.067 \\
\hline Male & 87 & 47.5 & 1.0 & - & 1.0 & - & \\
\hline Female & 87 & 57.6 & 1.5 & $1.0-2.3$ & 1.3 & $0.8-2.1$ & \\
\hline Well-child careat the health center ${ }^{\ddagger}$ & & & & & & & 0.215 \\
\hline Yes & 154 & 52.7 & 1.0 & - & & & \\
\hline No & 17 & 65.4 & 1.7 & $0.7-3.9$ & & & \\
\hline Child attendance at daycare $\mathrm{f}^{\ddagger}$ & & & & & & & 0.635 \\
\hline No attendance & 154 & 52.7 & 1.0 & - & & & \\
\hline Attendance & 20 & 48.8 & 0.8 & $0.4-1.6$ & & & \\
\hline \multicolumn{8}{|l|}{ Place of stay of the child who } \\
\hline does not attend daycare ${ }^{\ddagger}$ & & & & & & & 0.001 \\
\hline Parent's house & 128 & 48.7 & 1.0 & - & 1.0 & - & \\
\hline Another place & 22 & 81.5 & 4.6 & $1.7-12.6$ & 3.7 & $1.3-10.5$ & \\
\hline \multicolumn{8}{|l|}{ Primary caregiver of the child who } \\
\hline does not attend daycare $\ddagger$ & & & & & & & 0.005 \\
\hline Mother & 128 & 49.0 & 1.0 & - & & & \\
\hline Others & 26 & 74.3 & 3.0 & $1.3-6.6$ & & & \\
\hline
\end{tabular}

* Adjusted model for maternal education; + Chi-square test; $\neq$ Information was not obtained for the entire sample; Cl95\%=confidence interval of 95; OR=odds ratio; $G C D=$ general child development.

and $32.0 \% .24$ This result is very relevant because it indicates that one out of every two children registered in primary care facilities has not achieved some development milestone for their age.

In this situation, the Ministry of Health recommends that health professionals anticipate the next consultation, investigate the environmental situation of the child and the relationship with the mother, and to guide mothers on the importance of child development and the meaning of progression of the milestones for each age that are included in the Child Health Handbook. ${ }^{20}$ This document contains the Developmental Surveillance Instrument in Brazil.

Despite this recommendation, in a systematic review of the literature was identified the underutilization of the Developmental Surveillance Instrument in Brazil. ${ }^{17}$ In a study that evaluated different data included in the Child Health Handbook, the child development milestones were the most incomplete. 25

In relation to associated factors, both the general child development and all development domains were associated with the child's age. This reinforces the findings of other studies, which showed that child development depends on the child's age. 24,26

Thus, it is necessary to know the normal development of children according to their age group, so those in need for specialized care can be identified and timely referrals can be done. This way, they can receive a prompt and suitable intervention in order that children can achieve their full development potential.27 Under this principle, the American Pediatric Association establishes that every child must be evaluated for the early identification of developmental disorders. ${ }^{28}$

General child development was also associated with the place of stay of children who do not attend daycare. According to data from the National Survey by Continuous Household Sample, the public education and childcare systems fail to provide the necessary quantity of places in daycare centers for the care of children under three years of age. 29 
Consequently, mothers who work outside the home and cannot find places in public daycare centers or pay for private daycare, have to leave their children in places other than their home, with relatives, neighbors or other people. There is extensive evidence showing the influence of the environment on child development. 1,9,12,30 A possible assumption is that children who remain in a place other than their parents' home may receive lower-quality care with less interaction and fewer learning opportunities through experiences promoting the development.

In relation to the limitations of this study, the Developmental Surveillance Instrument included in the Child Health Handbook used in this study does not show diagnoses of developmental delays, which may have made it difficult to assess the factors associated with the absence of one or more development milestones.

Another limitation could refer to the size of the sample that was not specifically planned for the analysis of child development and may have been insufficient to detect significant differences for some variables, such as nutritional aspects.

However, this study enabled advances in aspects related to knowledge about the surveillance of child development in primary care and in the use of the official instrument recommended by the Ministry of
Health, which has been little used in scientific publications.

The high proportion of children with absence of development milestones identified with the official instrument of the Brazilian Ministry of Health is a very relevant result that needs to be widely disseminated and discussed with health professionals and those responsible for child care. The association with the child's age and the place of stay of children who do not attend daycare represent potentially important factors to be considered in developmental surveillance within primary health care.

\section{Authors' contribution}

Solís-Cordero K: data analysis, interpretation of results, writing, formatting and review of the article. Palombo CNT: conception and design of the project, data collection and writing of the article. Duarte LS:data collection, data analysis, interpretation of results and writing of the article. Munhoz RI: data collection and contributed to the writing of the article. Toriyama ATM and Borges ALV: writing and critical review of the content of the article. Fujimori E: project orientation, writing and review of the article. All the authors approved the final version of the article.

\section{References}

1. Lu C, Black MM, Richter LM Risk of poor development in young children in low-income and middle-income countries: an estimation and analysis at the global, regional, and country level. Lancet Glob Health. 2016; 4 (12): e916-e922.

2. Black MM, Walker SP, Fernald LCH, Andersen CT, DiGirolamo AM, Lu C, McCoy DC, Fink G, Shawar YR, Shiffman J, Devercelli AE, Wodon QT, Vargas-Barón E, Grantham-MCGregor S. Early childhood development coming of age: science through the life course. Lancet. 2017; 389(10064):77-90

3. Banco Interamericano de Desarrollo. Los primeros años: el bienestar infantil y el papel de las políticas públicas. Washington, DC: Banco Interamericano de Desarrollo; 2015 .

4. Halpern R, Barros AJ, Matijasevich A, Santos IS, Victora CG, Barros FC. Developmental status at age 12 months according to birth weight and family income: a comparison of two Brazilian birth cohorts. Cad Saúde Pública. 2008; 24 (Suppl. 3): S444-50

5. Alvim CG, Guimarães FG, Meinberg NLS, Aguiar LT, Caetano LCG, Carrusca LC, et al. A Avaliação do desenvolvimento infantil: um desafio interdisciplinar. Rev Bras Educ Med. 2012; 36 (1): 51-6.

6. Silva ACD, Engstron EM, Miranda CT. Fatores associados ao desenvolvimento neuropsicomotor em crianças de 6-18 meses de vida inseridas em creches públicas do Município de João Pessoa, Paraíba, Brasil. Cad Saúde Pública. 2015; 31 (9): 1881-93.

7. Coelho R, Ferreira JP, Sukiennik R, Halpern R. Child development in primary care: a surveillance proposal. $\mathrm{J}$ Pediatria. 2016; 92 (5): 505-11.

8. Oliveira CVR, Palombo CNT, Toriyama ATM, Veríssimo MLOR, Castro MC, Fujimori E. Health inequalities: child development in different social groups. Rev Esc Enferm USP. 2019;53:e03499.

9. Walker SP, Wachs TD, Meeks Gardner J, Lozoff B, Wasserman GA, Pollitt E, et al. Child development: risk factors for adverse outcomes in developing countries. Lancet. 2007; 369: 14-57.

10. Koh K. Maternal breastfeeding and children's cognitive development. Soc Sci Med. 2017; 187: 101-8.

11. Muñoz-Vinuesa A, Afonso-Martín A, Cruz-Quintana F, Pérez-Marfil MN, Sotomayor-Morales EM, FernándezAlcántara M. Determinantes sociales de lasalud. Estatus socioeconómico, neurodesarrollo y funciones ejecutivas en la infancia. Index Enferm. 2018; 27 (3): 143-6. Disponible en: http://ciberindex.com/index.php/ie/article/view/e11846 
12. Díaz AA, Bacallao Gallestey J, Vargas-Machuca R, Aguilar Velarde R. Desarrollo infantil en zonas pobres de Perú. Rev Panam Salud Publica. 2017; 41:1-8.

13. Brazelton TB, Greenspan SI. As necessidades essenciais das crianças: o que toda criança precisa para crescer, aprender e se desenvolver. Trad. Cristina Monteiro. Porto Alegre: Artmed, 2002.

14. Kostyrka-Allchorne K, Cooper NR, Simpson A. The relationship between television exposure and children's cognition and behaviour: A systematic review. Dev Rev. 2017; 44: $19-58$.

15. Brasil. Ministério da Saúde. Portaria $N^{0} 1.130$ de 5 de Agosto de 2015. Institui a Política Nacional de Atenção Integral à Saúde da Criança (PNAISC) no âmbito do sistema Único de Saúde (SUS). Brasília, DF; 2015.

16. Brasil. Presidência da República. Lei No 13.257: Marco Legal da Primeira Infância. Brasília, DF; 2016.

17. Almeida AC, Mendes LC, Sad IR, Ramos EG, Fonseca VM, Peixoto MVM. Uso de instrumento de acompanhamento do crescimento e desenvolvimento da criança no Brasil: Revisão Sistemática de Literatura. Rev Paul Pediatr. 2016; 34 (1): 122-31.

18. Palombo CNT. Aconselhamento nutricional na atenção básica: conhecimentos e práticas de profissionais, estado nutricional e alimentação da criança antes e após capacitação. [Tese]. São Paulo (São Paulo): Escola de Enfermagem da Universidade de São Paulo; 2016.

19. Brasil. Ministério da Saúde. Secretaria de Atenção à Saúde. Departamento de Ações Programáticas e Estratégicas.Caderneta de Saúde da Criança. Brasília, DF; 2005.

20. Brasil. Ministério da Saúde. Secretaria de Políticas de Saúde. Departamento de Atenção Básica. Saúde da criança: acompanhamento do crescimento e desenvolvimento infantil. Brasília, DF; 2002.

21. Brasil. Ministério da Saúde. Orientações para a coleta e análise de dados antropométricos em serviços de saúde: Norma Técnica do Sistema de Vigilância Alimentar e Nutricional - SISVAN. Brasília, DF; 2011.
22. OMS (Organización Mundial de la Salud). Concentraciones de hemoglobina para diagnosticar la anemia y evaluar su gravedad. Ginebra; 2011.

23. OMS (Organización Mundial de la Salud). Indicadores para evaluar las prácticas de alimentación del lactante y del niño pequeño: conclusiones de la reunión de consenso llevada a cabo del 6 al 8 de noviembre de 2007 en Washington, DC, EE.UU. Francia; 2009.

24. Guimarães AF, Carvalho DV de, Machado NÁA, Baptista RAN, Lemos SMA. Risco de atraso no desenvolvimento de crianças de dois a 24 meses e sua associação com a qualidade do estímulo familiar. Rev Paul Pediatr. 2013; 31 (4): 452-8.

25. Costa JSD, Cesar JA, Pattussi MP, Fontoura LP, Barazzetti L, Nunes MF,Gaedke MA, Uebel R. Assistência à criança: preenchimento da caderneta de saúde em municípios do semiárido brasileiro. Rev Bras Saúde Mater Infant. 2014; 14 (3): 219-27

26. Demirci A, Kartal M. The prevalence of developmental delay among children aged 3-60 months in Izmir, Turkey. Child Care Health Dev. 2016; 42(2): 213-9.

27. Figueiras ACM. Vigilância do desenvolvimento da criança. Bol Inst Saúde. 2015; 16 (1): 77-83.

28. American Academy of Pediatrics. Developmental Surveillance and Screening of Infants and Young Children. Pediatrics. 2001; 108 (1): 192-8.

29. IBGE (Instituto Brasileiro de Geografia e Estatística). Coordenação de Trabalho e Rendimento. Pesquisa Nacional por Amostra de Domicílios Continua: educação; 2017. Disponível em: https://biblioteca.ibge.gov.br/visualizacao/ livros/liv101576_informativo.pdf

30. Bick J, Nelson CA. Early adverse experiences and the developing brain. Neuropsychopharmacol. 2016; 41: 17796

Received on October 7, 2019.

Final version presented on May 30, 2020.

Approved on June 26, 2020. 